\title{
Evaluating the environmental impacts of dietary recommendations
}

\author{
Paul Behrens $s^{a, b, 1}$, Jessica C. Kiefte-de Jong ${ }^{b, c, d}$, Thijs Bosker ${ }^{a, b}$, João F. D. Rodrigues ${ }^{a}$, Arjan de Koning ${ }^{a}$, \\ and Arnold Tukker,

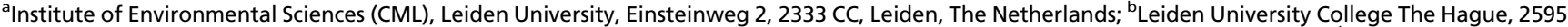 \\ DG, The Hague, The Netherlands; ' $\mathrm{C}$ epartment of Epidemiology, Erasmus Medical Center, $3015 \mathrm{CE}$, Rotterdam, The Netherlands; ${ }^{\mathrm{d} D e p a r t m e n t}$ of \\ Pediatrics, Erasmus Medical Center, 3015 CE, Rotterdam, The Netherlands; and ${ }^{\mathrm{e}}$ The Netherlands Organisation for Applied Scientific Research TNO, 2595 DA \\ Den Haag, The Netherlands
}

Edited by William C. Clark, Harvard University, Cambridge, MA, and approved October 31, 2017 (received for review July 3, 2017)

Dietary choices drive both health and environmental outcomes. Information on diets come from many sources, with nationally recommended diets (NRDs) by governmental or similar advisory bodies the most authoritative. Little or no attention is placed on the environmental impacts within NRDs. Here we quantify the impact of nation-specific NRDs, compared with an average diet in 37 nations, representing $64 \%$ of global population. We focus on greenhouse gases (GHGs), eutrophication, and land use because these have impacts reaching or exceeding planetary boundaries. We show that compared with average diets, NRDs in high-income nations are associated with reductions in GHG, eutrophication, and land use from 13.0 to $24.8 \%, 9.8$ to $21.3 \%$, and 5.7 to $17.6 \%$, respectively. In upper-middle-income nations, NRDs are associated with slight decrease in impacts of $0.8-12.2 \%, 7.7-19.4 \%$, and $7.2-18.6 \%$. In poorer middle-income nations, impacts increase by $12.4-17.0 \%$, $24.5-31.9 \%$, and $8.8-14.8 \%$. The reduced environmental impact in high-income countries is driven by reductions in calories ( $54 \%$ of effect) and a change in composition ( $46 \%)$. The increased environmental impacts of NRDs in low- and middle-income nations are associated with increased intake in animal products. Uniform adoption of NRDs across these nations would result in reductions of 0.19-0.53 Gt $\mathrm{CO}_{2} \mathrm{eq} \cdot \mathrm{a}^{-1}, 4.32-10.6 \mathrm{Gt} \mathrm{PO}_{4}^{3-} \mathrm{eq} \cdot \mathrm{a}^{-1}$, and 1.52.8 million $\mathrm{km}^{2}$, while providing the health cobenefits of adopting an NRD. As a small number of dietary guidelines are beginning to incorporate more general environmental concerns, we anticipate that this work will provide a standardized baseline for future work to optimize recommended diets further.

sustainable diets | MRIO | environmental impacts | dietary change

다임 od systems place large and increasing burdens on the environment (1). It is estimated that food production accounts for $19-29 \%$ of global greenhouse gas emissions (80-86\% of which are in agriculture) (2), drives eutrophication (3), and occupies $\sim 33 \%$ of the ice-free land globally (4). Furthermore, agricultural development threatens biodiversity (5) and can increase soil degradation (6). The increased environmental impact of food is driven by an increase in global population, in combination with a decrease in undernutrition (7). On top of this, recent trends show increasing demand for foods with high environmental impacts. For example, in the period 1993-2013 the demand for animal products increased $62 \%$, compared with a population increase of $29 \%(7)$. Although there are environmental impacts that could be eased with improved supply-side production techniques (8), there is a large scope for demand-side changes through individual dietary choice, in terms of both food choices and quantities consumed (9). Careful consideration of choices, although ensuring sufficient macronutrient and micronutrient intake, may also result in a cobenefit because in general, environmentally friendly dietary choices can confer large cobenefits in health outcomes (10).

National recommended diets (NRDs) are an important policy tool for providing nutritional advice (11). Initially, NRDs focused on nutrients to ensure an adequate intake (12), indirectly encouraging the consumption of animal products. Current NRDs in high-income nations typically have an increasing emphasis on vegetal products. In contrast, NRDs in lower-income nations address concerns about sufficient caloric and protein intake by recommending high amounts of both. However, as these nations undergo the nutrition transition whereby diets shift from plant-based staples to an increased intake of animal-based and processed foods, this may result in situations where undernutrition and obesity can coexist (commonly termed the double burden of malnutrition) (13). Generally, NRDs in lowerincome nations have not adapted to this transition (14).

NRDs are a potentially important policy tool for decreasing environmental impacts, but to date, NRDs have generally omitted any discussion of the environmental impacts of diets. Environmental factors are mentioned in just four NRDs surveyed here: those for Sweden, The Netherlands, the United Kingdom, and China in order of strength of focus (Supporting Information). In all four cases, this does not extend further than a qualitative suggestion that environmental sustainability could be considered in food choices and that the consumption of meat could be reduced Although most national guidelines do not consider environmental sustainability, following them may be associated with changes in environmental impacts because they typically recommend changes in dietary composition and volume on health grounds (15). To date this has only been investigated on a country-specific basis in high-income nations using life cycle assessment (LCA) methods. Although valuable, due to the emphasis on LCA these studies are

\section{Significance}

Nationally recommended diets are a prominent method for informing the public on dietary choices. Although dietary choices drive both health and environmental outcomes, these diets make almost no reference to environmental impacts. Our study provides a comparison between the environmental impacts of average dietary intakes and a nation-specific recommended diet across 37 middle- and high-income nations. We find that following a nationally recommended diet in highincome nations results in a reduction in greenhouse gases, eutrophication, and land use. In upper-middle-income nations, we find a smaller reduction in impacts, and in lower-middle-income nations we find a substantial increase. The net result from largescale adoption of nationally recommended diets for countries studied here results in a reduction in environmental impacts.

Author contributions: P.B. designed research; P.B. performed research; P.B., T.B., and J.C.K.-d.J. analyzed data; and P.B., J.C.K.-d.J., T.B., J.F.D.R., A.d.K., and A.T. wrote the paper.

The authors declare no conflict of interest.

This article is a PNAS Direct Submission.

This open access article is distributed under Creative Commons Attribution-NonCommercialNoDerivatives License 4.0 (CC BY-NC-ND).

Data deposition: Software code is available online at https://github.com/PaulBehrens/ EvaluatingEnvironmentaINRD.

${ }^{1}$ To whom correspondence should be addressed. Email: p.a.behrens@luc.leidenuniv.nl.

This article contains supporting information online at www.pnas.org/lookup/suppl/doi:10. 1073/pnas.1711889114/-/DCSupplemental. 
difficult to compare (16) and leave middle-income nations underrepresented $(6,17,18)$.

Here we provide a large-scale assessment of the environmental impacts of average diets, directly comparing them to nationspecific NRDs. We focus on three key environmental threatsclimate change, eutrophication potential [for ease of presentation we show only $\mathrm{PO}_{4}^{3-}$ eq; however, results for $\mathrm{NO}_{x}$ eq were closely correlated (Fig. S10)], and land use-because these are exceeding or close to exceeding the planetary boundaries (see below for further discussion) (19), and reductions are increasingly urgent.

We include 9 middle-income nations and 28 high-income nations for which NRDs are available, representing $64 \%$ of the global population. We split the nine middle-income nations into lower-middle (India and Indonesia) and upper-middle (remaining) using World Bank categories (20). We use nation-specific diets because dietary composition and advice are driven by local concerns. To assess the environmental impacts, we take a consumptionbased approach in which dietary change in one country incorporates the environmental impacts both locally (domestically produced food) and globally (imported food). To do this, we collect nationspecific NRDs from primary sources and average national diets from Food and Agriculture Organization (FAO) food balance sheets. To compare like with like, we subtracted consumer wastes from the average national diets; harmonized the food categories in NRDs and average diets; and scaled NRDs so that the total caloric intake matches that of the average diets, whereas original proportion of different food categories was respected (isocaloric approach). Dietary data were coupled with a multiregional, environmentally extended, input-output (MRIO) database (which is already unified with bulk FAO data and categorizations). This approach allows for a trade-based accounting of environmental impacts associated with diets (full details are available in Materials and Methods).

\section{Results and Discussion}

Characterization of Average and Recommended Diets. In general, NRDs are specific to the health challenges from diets found in that nation. For example, India focuses on increasing caloric and nutritional content (21), whereas the United States focuses on reducing caloric intake (22). Compared with average national diets, NRDs generally recommend a substantial reduction in sugars, oils, meat, and dairy (Fig. 1 and Figs. S2-S4). These reductions are largest in high-income nations, where fruit, vegetables, and nuts are generally recommended for replacement calories. These changes are very large and would require significant departures from current dietary patterns. It is likely that any shifts to these recommended diets would occur gradually. These general trends are similar for upper-middle-income nations but with less reduction in meat and several nations recommending replacement calories from dairy. India and Indonesia, both lower-middle-income nations, are the only nations with recommendations for increases in meat intake. This may be partly due to the relatively high prevalence of undernutrition and micronutrient deficiencies in these regions.

However, even in these cases the increase is small, and replacement calories from fruit, vegetables, and nuts are recommended, as in the case for high-income nations. In general, there is very little change in the consumption of fish in all nations, with high-income nations recommending a small reduction and middleincome nations recommending a moderate increase. Some eastern European nations have recommended diets showing very little change with respect to the average diet; this may be partially due to the fact that these guidelines have not been updated for some time and partly due to continuing concerns of undernutrition in some sectors (i.e., rural communities) of those societies $(23,24)$.

In average diets, the most important source of energy is grains, which is greater in middle-income nations than in high-income nations (Fig. S1). The second biggest source of energy is dairy, which is higher in high-income nations compared with middleincome nations (Fig. S1). Fats compose less dietary energy in middleincome nations compared with high-income nations (Fig. S1). This is also true for protein intake but is less pronounced. The relative contribution of protein to overall energy intake varies between 10 and

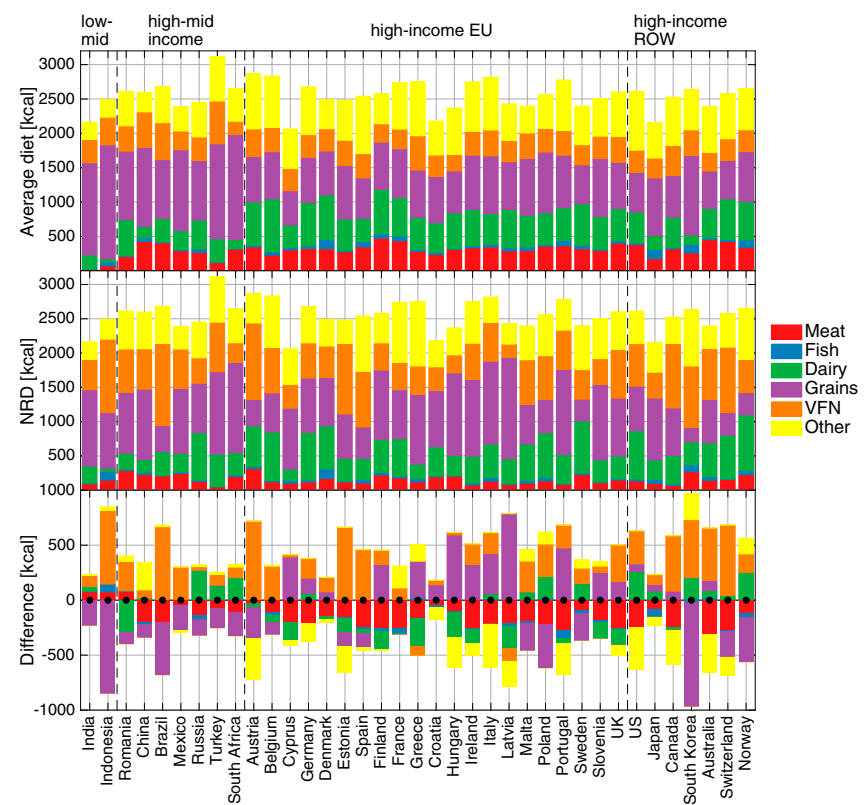

Fig. 1. Overview of the composition of energy intake by food category per person per day for national average diets, national recommended diets, and the difference between them, for all countries in this study. Notice that NRDs have been scaled so that total calorie intake matches that of the average diet (isocaloric approach). Although the proportion of grains for Hungary, Latvia, and Portugal may seem large, these are the recommendations (Supporting Information).

$15 \%$ of the total energy. Meat and dairy are the most important contributors to protein intake in most nations except for Turkey, South Africa, Indonesia, India, and China. In all nations, the contribution of fat is mainly from dairy and other foods (i.e., oils).

Environmental Impacts of Average Diets. The greenhouse gas (GHG) emission impacts for average diets significantly increase with income, from $1.1 \mathrm{~kg} \mathrm{CO}_{2}$ eq per person per day $\left(\mathrm{p}^{-1} \cdot \mathrm{d}^{-1}\right)$ in lower-middle-income nations to $1.6 \mathrm{CO}_{2} \mathrm{eq} \cdot \mathrm{p}^{-1} \cdot \mathrm{d}^{-1}$ for uppermiddle-income nations and $2.4 \mathrm{~kg} \mathrm{CO} 2 \mathrm{eq} \cdot \mathrm{p}^{-1} \cdot \mathrm{d}^{-1}$ for high-income nations (Fig. $2 A$ ). Animal products (meat, fish, and dairy) account for $22 \%, 65 \%$, and $70 \%$ of emissions in the diets of lower-middle-, upper-middle-, and high-income nations, respectively. Some nations show very different impacts to counterparts within the same group, with Brazil and Australia having emissions over 200\% higher than the average of their respective income groups and driven by meat consumption. This is likely due to both the amount of meat in the diet and the preponderance of grass-fed beef within both of these regions, associated with higher methane emissions than grain-fed beef (25). Although not as extreme, the United States, Canada, and Norway have emissions $40 \%$ higher than the average of their income group, with meat, dairy, and fish contributing larger amounts than the average, respectively. In the United States and Canada this is also likely due to grass-fed cattle; in Norway, fishing contributes more than in other regions, due to both demand and fuel-intensive fleets (26).

In general, eutrophication impacts follow a similar pattern as GHG impacts, increasing from $13.1 \mathrm{~kg} \mathrm{PO}{ }_{4}^{3-} \mathrm{eq} \cdot \mathrm{p}^{-1} \cdot \mathrm{d}^{-1}$ in lowermiddle-income nations, to $32.5 \mathrm{~kg} \mathrm{PO}_{4}^{3-} \mathrm{eq} \cdot \mathrm{p}^{-1} \cdot \mathrm{d}^{-1}$ for uppermiddle-income nations, then down slightly to $32.1 \mathrm{~kg} \mathrm{PO} \mathrm{PO}_{4}^{3-} \mathrm{eq} \cdot \mathrm{p}^{-1} \cdot \mathrm{d}^{-1}$ for high-income nations. The increases in eutrophication impacts due to animal products in Brazil, Australia, Canada, and the United States are larger than those for GHGs, with 121, 119, 57, and $59 \mathrm{~kg} \mathrm{PO} \mathrm{PO}_{4}^{3-} \mathrm{eq} \cdot \mathrm{p}^{-1} \cdot \mathrm{d}^{-1}$, respectively. Again, this is likely due to the preference for extensive grass grazing of cattle in these regions compared with other nations. 

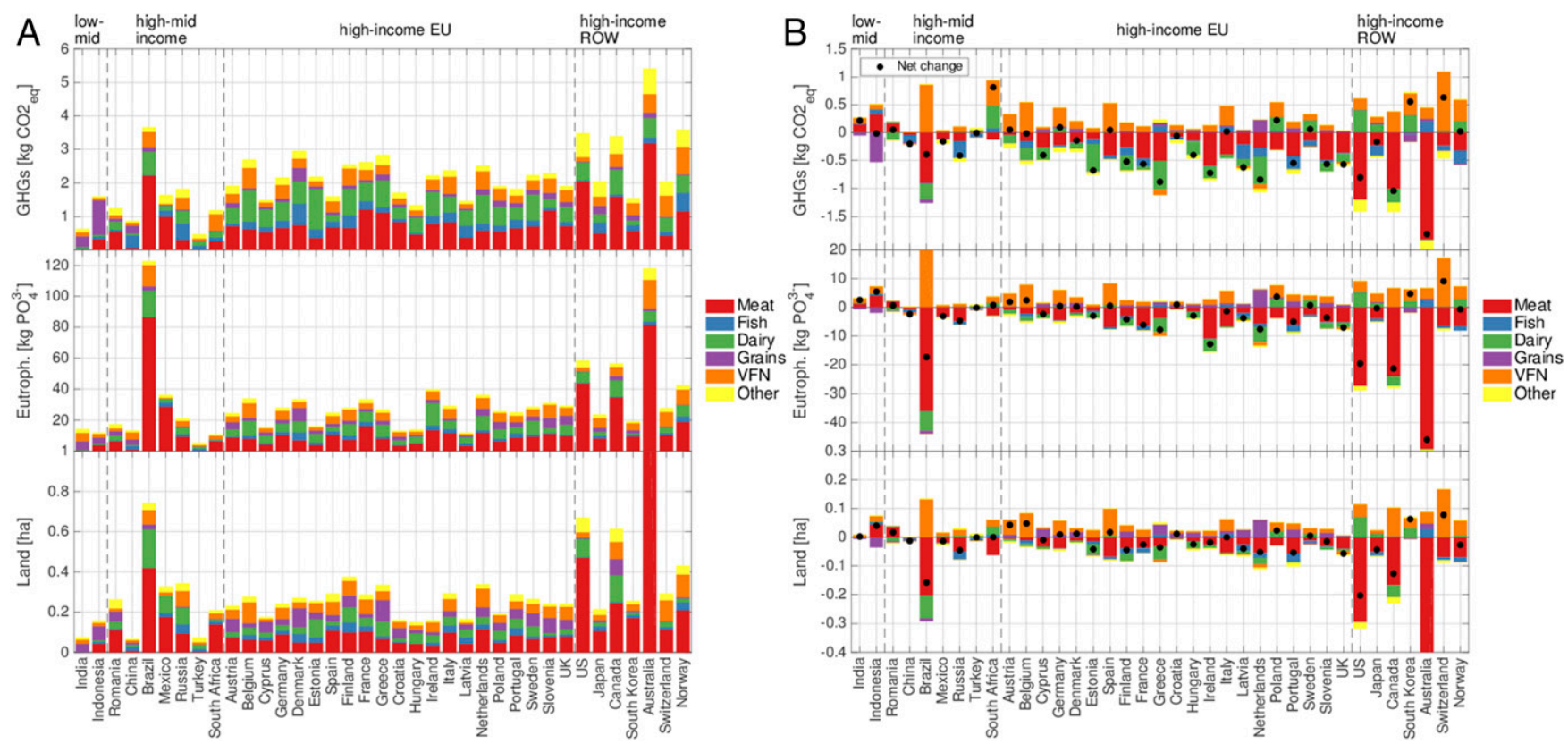

Fig. 2. (A) Absolute environmental impacts of average diets for different national income groups per person. (B) Differences in environmental impacts between average and recommended diets per person. Net change and change by food group are shown. Both panels give GHG and eutrophication emissions in terms of per day and land use in ongoing, yearly requirement. Land use in Australia has been truncated in both panels for ease of visualization (in $A$, total Australian land use is $3.3 \mathrm{ha}$; in $B$ the change is a reduction of $1.0 \mathrm{ha}$ ).

Average land use also follows similar patterns to those of emissions but with a smaller difference between lower-middleand upper-middle-income nations, varying between 0.11 ha. $\mathrm{p}^{-1}$ for lower-income nations, $0.29 \mathrm{ha} \cdot \mathrm{p}^{-1}$ for middle-income nations, and $0.39 \mathrm{ha} \cdot \mathrm{p}^{-1}$ for high-income nations. The average land use in high-income nations was over 3.5 times that of the low-middleincome average.

The absolute estimates of the environmental impacts of estimated average diets reported in the current study are in the same order of magnitude, but slightly lower, than those within the LCA literature more generally (6). One reason for these differences arises from the fact that here we consider foods in diets only and omit emissions from cooking, preparation, and waste. Other factors that can lead to discrepancies between input-output analyses and LCA results are differences in allocation and aggregation $(27,28)$.

Environmental Impacts of Shifting to Nationally Recommended Diets. Environmental impacts of shifting from average to nationally recommended diets vary across nations and income groups (Figs. $2 B$ and $3)$. High-income nations see the greatest reduction in impacts due to dietary shifts, with an average reduction of $0.34 \mathrm{~kg} \mathrm{CO}$ eq. $\mathrm{p}^{-1} \cdot \mathrm{d}^{-1}$ $(-13.0 \%), 4.7 \mathrm{~kg} \mathrm{PO}_{4}^{3-} \mathrm{eq} \cdot \mathrm{p}^{-1} \cdot \mathrm{d}^{-1}(-9.8 \%)$, and $0.07 \mathrm{ha} \cdot \mathrm{p}^{-1}(-5.7 \%)$. If shifts in caloric intake are also considered, these reductions increase to $0.63 \mathrm{~kg} \mathrm{CO} 2 \mathrm{eq} \cdot \mathrm{p}^{-1} \cdot \mathrm{d}^{-1}(-24.7 \%), 8.3 \mathrm{~kg} \mathrm{PO} \mathrm{PO}_{4}^{3-} \mathrm{eq} \cdot \mathrm{p}^{-1} \cdot \mathrm{d}^{-1}$ $(-21.3 \%)$, and 0.1 ha. $\mathrm{p}^{-1}(-17.6 \%)$ (see Fig. S4 for more information). In middle-income nations, marginal reductions are observed, with changes of $0.01 \mathrm{~kg} \mathrm{CO} 2 \mathrm{eq} \cdot \mathrm{p}^{-1} \cdot \mathrm{d}^{-1}(4.4 \%), 2.0 \mathrm{~kg}$ $\mathrm{PO}_{4}^{3-} \mathrm{eq} \cdot \mathrm{p}^{-1} \cdot \mathrm{d}^{-1}(1.1 \%)$, and $0.02 \mathrm{ha} \cdot \mathrm{p}^{-1}(-2.3 \%)$. Isolating to upper-middle-income nations only by omitting the different trends in the two lower-middle-income nations, India and Indonesia, gives average reductions of $0.04 \mathrm{~kg} \mathrm{CO} 2 \mathrm{eq} \cdot \mathrm{p}^{-1} \cdot \mathrm{d}^{-1}$ $(-0.8 \%), 3.8 \mathrm{~kg} \mathrm{PO} 4^{3-}$ eq. $\mathrm{p}^{-1} \cdot \mathrm{d}^{-1}(-7.7 \%)$, and $0.03 \mathrm{ha} \cdot \mathrm{p}^{-1}(-7.2 \%)$. Large-scale adoption of NRDs implies increases in impacts from lower-middle-income nations and decreases in other income categories. The net result of following NRDs for the countries examined here results in reductions of $0.19 \mathrm{Gt} \mathrm{CO}_{2} \mathrm{eq}^{-\mathrm{a}^{-1}}$ and 4.32 $\mathrm{Gt}^{\mathrm{PO}_{4}^{3-}} \mathrm{eq} \cdot \mathrm{a}^{-1}$ in an isocaloric estimate and $0.53 \mathrm{Gt} \mathrm{CO}_{2} \mathrm{eq} \cdot \mathrm{a}^{-1}$ and $10.6 \mathrm{Gt} \mathrm{PO}_{4}^{3-} \mathrm{eq} \cdot \mathrm{a}^{-1}$ in a nonisocaloric estimate.
Exceptions to trends in high-income nations, showing larger $\left(>0.1 \mathrm{~kg} \mathrm{CO} \mathrm{CO}_{2} \mathrm{eq} \cdot \mathrm{p}^{-1} \cdot \mathrm{d}^{-1}\right)$ increases in environmental impacts associated with NRDs, are Poland, South Korea, and Switzerland. In all cases, this is partially due to increasing amounts of vegetables, fruits, and nuts. In Switzerland, vegetables, fruits, and nuts make up the total increase and may be due to the use of greenhouses and heating oil in particular (29). In Poland and South Korea, higher recommendations for dairy also contribute to increasing environmental impacts. In middle-income nations, clear exceptions are Brazil and South Africa. In Brazil, large reductions are from meat and dairy, as discussed above. The increases in South Africa relative to other nations in the income group are due to dairy and increased vegetables, fruits, and nuts. South Africa has historically suffered from a high prevalence of undernutrition but, after several decades of transition, now has a high rate of obesity due to a shift to a diet high in fat, simple sugars, and animal-based foods (30). However, the South African NRD suggests even greater intake of dairy products, which may indicate that the advice has failed to keep up with developing dietary changes among some sections of the population, especially among the urban population. The advice may still be appropriate for the rural poor where undernutrition and micronutrient deficiencies are common. In lower-middle-income nations, India and Indonesia, impacts from following recommended diets are associated with an increase in impacts of $0.1 \mathrm{~kg} \mathrm{CO} 2 \mathrm{eq} \cdot \mathrm{p}^{-1} \cdot \mathrm{d}^{-1}(+17.0 \%), 4.0 \mathrm{~kg} \mathrm{PO}{ }_{4}^{3-}$ eq. $\mathrm{p}^{-1} \cdot \mathrm{d}^{-1}$ $(32.0 \%)$, and 0.02 ha $\cdot \mathrm{p}^{-1}(14.8 \%)$. This is predominately driven by increased meat and fish intake. These increases move the absolute impacts of NRDs in lower-middle-income nations closer to those in high-income nations. If both income groups adopted NRDs over current average diets, lower-middle-income diets move from $47 \%$ of the GHG impact of high-income diets to $67.4 \%$.

In terms of food groups, changes in meat and dairy intake would result in a significant reduction in GHG emission, eutrophication, and land use in all countries except three lowerincome nations, India, Indonesia, and Romania. Changes in the intake of vegetables, fruits, and nuts will result in an increase in GHGs emission, eutrophication, and land use for all countries except Greece and The Netherlands (Fig. 2B). In some specific 


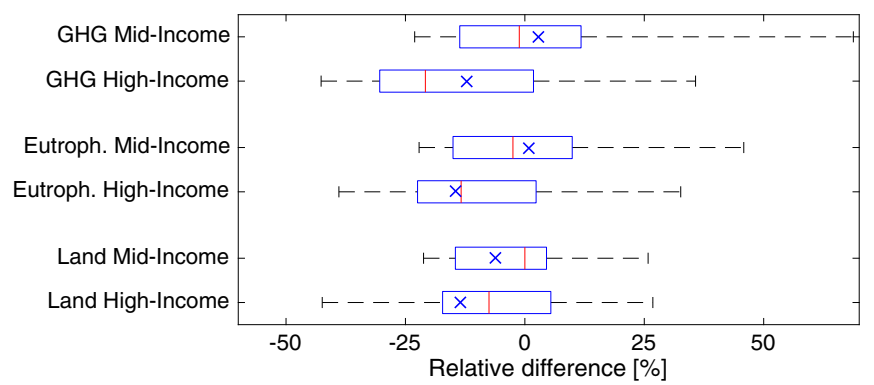

Fig. 3. Relative differences in environmental impacts between nationally recommended and average diets for high-income and lower-income nations. Red line indicates median relative difference; left and right box limits show first and third quartiles, respectively; whiskers show range from minimum to maximum; and blue crosses show the mean, population-weighted impact.

cases, such as the United States and Australia, significant reductions also arise from limiting fats and sugars.

Trade Impacts. Trade-linked data allow for a further investigation of embodied environmental impacts in imports of foods related to average and recommended diets. In general, for average diets, the largest global food producers and exporters show the lowest imports of embodied GHGs, for example, the United States, Brazil, Europe, and Australia. In contrast, Japan, Russia, and Canada show large imports of embodied GHGs. Diets associated with NRDs increase import dependence in Australia and Canada while reducing import dependence significantly in Japan, and less so in Brazil, South Africa, India, and Russia (Figs. S7-S9).

Further Opportunities in NRDs. The environmental impacts of NRDs vary widely among nations because their emphasis is driven by local dietary concerns (Fig. $2 B$ and Fig. S2). Many middle-income nations have greater recommended meat intake than high-income nations, likely due to the relatively high prevalence of protein energy malnutrition and widespread micronutrient malnutrition, especially where large-scale food fortification programs have limited reach. These recommendations could be improved from an environmental perspective by advising the substitution of meat-based with plant-based proteins, such as legumes and nuts, as has been done in most highincome nations. Some nations recommend a reduction of red meat specifically or substitution with white meat for health reasons (31). Although this does align with environmental outcomes by reducing ruminant consumption, this still may lead to a relatively high (lean or white) meat intake, which has still disproportionate environmental impacts compared with other food types (32). Here we have focused on an isocaloric analysis whereby NRDs are altered such that the proportion of the different food categories matches that of the original NRD, but the overall caloric intake is scaled so that it matches that of the current average diet (Materials and Methods). An alternative way to harmonize the NRDs would be to scale the caloric intake not to a country-specific average but to the caloric intake recommended by global guidelines of $\sim 2,200 \mathrm{kcal} \cdot \mathrm{p}^{-1} \cdot \mathrm{d}^{-1}$ (33). National recommended diets average around that same value; thus, such an analysis would be very close to the analysis of the nonisocaloric NRD (Fig. S4).

As this work shows, different issues and thus impacts are prevalent around the world depending on income. For example, further impact mitigation in high-income nations may be achieved by lowering the recommendations for dairy, which remains an important contributor of GHG emissions in many nations even under recommendation-compliant diets. However, although partial replacement of meat and dairy by plant-derived food sources does not substantially change the adequacy of nutrient intake $(34,35)$, the extent to which this can be applied in NRDs and then extrapolated globally needs to be established. Furthermore, in highincome nations, countries with high fish intake (Mediterranean and Scandinavia) show large reductions in land use relative to other nations. A high intake of fish is increasingly popular in new recommendations for nutritional reasons, but amounts may be lowered while still aligning desired health outcomes (36) with concerns about biodiversity loss in food marine webs (37). Several studies have shown that dietary quality varies not only between nations but also regionally within countries, for example, by socioeconomic background (38), ethnic background $(39,40)$, or rural vs. urban areas (41). Further research based on individual dietary data globally is needed to translate our results within countries, such as for specific subgroups, especially disadvantaged groups.

Overall, our results show that in many cases, there are environmental impact benefits to adopting NRDs. At present these benefits are smaller than other interventions in the environmental impact of food systems such as reductions in food waste (42). Further benefits from NRDs could be derived by incorporating sustainability further into the recommendations. In general, in high-income nations, a reduction in the recommended intake of (nonred) meat, dairy, and fish products would be beneficial on both accounts. NRDs for lower-middle- and upper-middle-income nations will also have to be adapted quickly as those countries develop and experience shifts in average diets. These shifts will have to be cognizant of the continuing challenges of the double burden of malnutrition. Although some countries have incorporated recommendations related to sustainable diets, implementing actual sustainable dietary guidelines remains challenging. For example, the 2016 Dietary Guidelines for Americans recommend increasing fruit and vegetable consumption, but current national production is insufficient to accommodate the adoption of this specific guideline by the majority of US citizens (43). In addition, there are tensions between the environmental and health impacts of fruit and vegetables grown in greenhouses or in countries where unseasonal production is high, such as in the United Kingdom (44). As a result, it will likely be necessary to tailor sustainable dietary recommendations to regional and cultural circumstances. This principle has been successfully applied in the new Nordic dietary recommendations and the Mediterranean diet (45). The work presented here will help policy makers quantify and optimize NRDs from an environmental perspective, building on the current knowledge of sustainable diets, which is important because consumers on their own are more likely to follow dietary guidelines developed with a health outcome in mind, rather than an environmental one (46).

\section{Materials and Methods}

Construction of Average National Diets. Source data for average national diets were obtained from FAO food balance sheets (FBSs), which were then adjusted (47). Supply quantity data give nationwide plant and animal food supply from production plus imports for 19 broad food groups, which consist of a further 88 subgroups. Values are adjusted for stock changes exports, quantities used for seed, animal feed, and the manufacture of nonfood products. Data are available as calories (kilocalories per person per day), weights (grams per person per day), protein (grams per person per day), and fats (grams per person per day) for and for all countries used in this study. Although these data include wastes from processing, packaging, and transport, they do not include consumer waste and so do not correspond to the average consumed diet. There may be further variations in overall results from changes in cooking times and technologies not captured herein. Consumer wastes were subtracted from the food quantity using ref. 48, which provides estimates for five different waste types for seven different food types in seven different regions of the world. This results in a final estimate for the average diet in each nation, comprising the grams consumed of food subgroup per person per day (see Fig. S1 for an overview and Supporting Information and Dataset S1 for a complete review). Consideration was made to use national food surveys instead of FBSs; however, although raw supply quantity data may overestimate intake (49), national food surveys are likely to underestimate intake due to underreporting. For example, the National Health and Nutrition Examination survey in the United States found an average intake between 2009 and 2010 of 2,081 calories per day, which is not likely to reflect actual intake (50). 
Construction of Nationally Recommended Diets. NRDs were collected from the national organizations tasked with providing dietary advice (for all references, see Table S1). In every country except Indonesia, this was either a governmental organization or a national nutritional society. Indonesian guidelines were taken from an article in the peer-reviewed literature (51).

Measurement types used in NRDs vary across nations, and although they generally use grams, they can also include cups, portions, servings, and handfuls. Where the amount in grams was not available in the NRD, a conversion was made to grams (52). For guidelines providing choices between different, broad food groups (e.g., citizens are recommended $65 \mathrm{~g}$ of meat or fish daily), quantities were split using proportions in the average diet. This conforms with the assumption that consumers would follow guidelines in proportion to their existing diet in the absence of further advice. Raw data from the NRD collection are available for review in Supporting Information.

Concordances were made between the food groups available in the NRDs and the 88 food subgroups in FAO data. If the specific NRD did not provide advice on a particular food group, we made the assumption that the consumer would not alter their consumption habits of this food group. In these cases, we used the national average as calculated above. Finally, although many guidelines recommend reductions in the empty calories (such as sugars, alcoholic beverages, etc.) consumed per day, most had no specific recommendation for the amount. We took the approach included in the United States NRD, recommending no more than 350 empty calories per person per day (22). Where intake exceeded 350 calories per day, the amount was reduced proportionally across all empty calorie food groups to the 350-calorie limit. This results in a final estimate of a recommendation-compliant diet for each nation, comprising the grams consumed of food subgroup per person per day. The difference between the average and recommendation-compliant diet is shown in Figs. S3 and S4. Finally, to avoid issues with comparing caloric intake across different nations (with differing environmental, activity, and ethnic backgrounds), an isocaloric diet was constructed by scaling the NRD up to the caloric intake of the FAO estimated average diet (while maintaining the 350-calorie limit for empty food groups). It is this isocaloric diet on which we focus most of our analysis.

Computing Environmental Impacts. We use EXIOBASE 3.3 (53), an environmentally extended multiregional input-ouput database [Exiobase 2.7 (for the year 2007) is available at www.exiobase.eu/] to derive environmental pressures associated with average and nationally recommended diets. EXIOBASE 3.3 describes the world economy for a set of 49 countries and world regions in 2011. This database was chosen on the basis of robust and diverse data and because it matches the nations for which NRDs are available. Product detail includes 200 categories, of which 12 are food groups. Food products within EXIOBASE were computed using FAO food groups and data. There are a large number of environmental and resource extensions in the database $(>2,000)$; however, we focus on greenhouse gases, eutrophication, and land use because these dominate planetary boundary and food

1. Foley JA (2005) Global consequences of land use. Science 309:570-574.

2. Vermeulen SJ, Campbell BM, Ingram JSI (2012) Climate change and food systems. Annu Rev Environ Resour 37:195-222.

3. Carpenter SR (2005) Eutrophication of aquatic ecosystems: Bistability and soil phos phorus. Proc Natl Acad Sci USA 102:10002-10005.

4. Whitmee S, et al. (2015) Safeguarding human health in the Anthropocene epoch Report of The Rockefeller Foundation-Lancet Commission on planetary health. Lancet 386:1973-2028.

5. Machovina B, Feeley KJ, Ripple WJ (2015) Biodiversity conservation: The key is reducing meat consumption. Sci Total Environ 536:419-431.

6. Aleksandrowicz L, Green R, Joy EJM, Smith P, Haines A (2016) The impacts of dietary change on greenhouse gas emissions, land use, water use, and health: A systematic review. PLoS One 11:e0165797.

7. Food and Agriculture Organization (2014) State of Food Insecurity in the World 2014 In Brief (Food Agric Organ, Rome).

8. Niles M, et al. (2017) Climate change \& food systems: Assessing impacts and opportunities. Available at bit.ly/2oFucpe. Accessed November 10, 2017.

9. Garnett T (2012) Where are the best opportunities for reducing greenhouse gas emissions in the food system (including the food chain)? A comment. Food Policy 36:463-466.

10. Tukker A, et al. (2011) Environmental impacts of changes to healthier diets in Europe. Ecol Econ 70:1776-1788.

11. Story M, Kaphingst KM, Robinson-O'Brien R, Glanz K (2008) Creating healthy food and eating environments: Policy and environmental approaches. Annu Rev Public Health 29:253-272.

12. Clay WD (1997) Preparation and Use of Food-Based Dietary Guidelines. Available at www.fao.org/docrep/W5849T/w5849t0a.htm. Accessed November 10, 2017.

13. Popkin BM (2006) Global nutrition dynamics: The world is shifting rapidly toward a diet linked with noncommunicable diseases. Am J Clin Nutr 84:289-298.

14. Sunguya BF, et al. (2014) Strong nutrition governance is a key to addressing nutrition transition in low and middle-income countries: Review of countries' nutrition policies. Nutr J 13:65. systems pressures $(4,19)$. Eutrophication was calculated using $\mathrm{kg} \mathrm{PO}_{4}^{3-}$ equivalent (54). Relationships for $\mathrm{N}_{2}$ followed a similar trend across nations and food groups (Fig. S10).

Algebraically, the environmental pressures, $\Delta r$ stimulated from a demand of food purchases in a diet $\Delta y$ can be calculated using the Leontief model (55).

$$
\Delta r=\boldsymbol{b}^{\prime}(\boldsymbol{I}-\boldsymbol{A})^{-1} \Delta \boldsymbol{y},
$$

where bold denotes a matrix object and italic denotes a scalar, uppercase denotes a matrix and lowercase denotes a vector, and the prime symbol denotes the transpose. Object $b$ is the vector of intervention coefficients, $(\boldsymbol{I}-\boldsymbol{A})^{-1}$ is the Leontief inverse or total requirement matrix $\boldsymbol{L}$, and $\boldsymbol{A}$ is the matrix of technical coefficients. Coefficient $b_{i}$ expresses the amount of intervention that occurs per unit of total output of industry $i$. Total requirement $L_{i j}$ expresses the total output of industry $i$ that is stimulated by a unit demand for product $j$. Direct requirement $A_{i j}$ expresses the purchases of $i$ that are required to generate one unit of output of $j$. In this conventional model $\Delta y$, the change in final demand is the (exogenous) control variable, $\boldsymbol{A}$ and $\boldsymbol{b}$ are parameters, and $\Delta \boldsymbol{r}$ is the (endogenous) return variable. A series of consumption vectors are calculated for an average diet and a nationally recommended diet, per person per year (because EXIOBASE represents a snapshot of the year). The vectors represent the total purchases in each food product group required for that final demand due to that diet.

Construction of Stimulus Vectors. The average and nationally recommended diets outlined above are represented as the number of grams consumed of FAO food subgroup per person per day. First, the diets represented by the 88 food subgroups available in FAO data were aggregated to the 12 available in EXIOBASE using concordance matrices (available in Supporting Information). These diets were then computed as the purchased amount per food group in purchaser prices (in Euros). To do this, the purchaser prices per gram of each food product category in each nation for 2011 were computed by dividing the total, national final demand of the food product category, by the FAO food supply quantity data outlined above, before subtraction of the consumer wastes. The purchaser prices of each food group in Euros pe gram for each nation were then multiplied by the number of grams of consumption under each diet to give the stimulus vectors described above.

Reporting of Results. Analysis was performed for the 37 nations available in EXIOBASE for different income groups as defined by the World Bank (Supporting Information). Impact analysis was performed for 12 food products, but for ease of inspection, results are reported in six categories: meat; fish dairy; grains; vegetables, fruits, and nuts (VFN); and other, including empty calories.

15. Montagnese C, et al. (2015) European food-based dietary guidelines: A comparison and update. Nutrition 31:908-915.

16. Ayres RU (1995) Life cycle analysis: A critique. Resour Conserv Recycl 14:199-223.

17. Arenas $A B$, et al. (2015) Guía Alimentaria y Actividad Física. Available at guiasalimentacionyactividadfisica.org.mx/wp-content/uploads/2015/10/Guias-alimentariasy-de-actividad-fisica.pdf. Accessed November 10, 2017.

18. Udo De Haes HA (2004) Life-cycle assessment and developing countries. J Ind Eco/ 8 8-10.

19. Steffen W, et al. (2015) Sustainability. Planetary boundaries: Guiding human development on a changing planet. Science 347:1259855.

20. World Bank (2016) World Bank country and lending groups. Available at https:/ datahelpdesk.worldbank.org/knowledgebase/articles/906519-world-bank-country-andlending-groups. Accessed November 10, 2017.

21. National Institute of Nutrition (2011) Dietary Guidelines for Indians-A Manual. Available at ninindia.org/DietaryGuidelinesforNINwebsite.pdf. Accessed November 10, 2017.

22. US Department of Health and Human Services and US Department of Agriculture (2015) Dietary Guidelines for Americans, 2015-2020, 8th Ed, Available at http://health gov/dietaryguidelines/2015/guidelines/. Accessed November 10, 2017.

23. Imre R, et al. (2004) Táplálkozási ajánlások a magyarországi felnött lakosság számára. Available at www.fao.org/3/a-as684o.pdf. Accessed November 10, 2017. Hungarian.

24. Degac KA, et al. (2002) Prehrambene smjernice za odrasle. Available at www.fao.org/ 3/a-as670o.pdf. Accessed November 10, 2017. Croatian.

25. Harper LA, Denmead OT, Freney JR, Byers FM (1999) Direct measurements of methane emissions from grazing and feedlot cattle. J Anim Sci 77:1392-1401.

26. Tyedmers PH, Watson R, Pauly D (2005) Fueling global fishing fleets. AMBIO A J Hum Environ 34:635-638.

27. Notarnicola B, Tassielli G, Renzulli PA, Castellani V, Sala S (2017) Environmental im pacts of food consumption in Europe. J Clean Prod 140:753-765.

28. Majeau-Bettez G, Strømman AH, Hertwich EG (2011) Evaluation of process- and inputoutput-based life cycle inventory data with regard to truncation and aggregation issues. Environ Sci Technol 45:10170-10177. 
29. Stoessel F, Juraske R, Pfister S, Hellweg S (2012) Life cycle inventory and carbon and water FoodPrint of fruits and vegetables: Application to a Swiss retailer. Environ $\mathrm{SCi}$ Technol 46:3253-3262.

30. Nnyepi MS, Gwisai N, Lekgoa M, Seru T (2015) Evidence of nutrition transition in Southern Africa. Proc Nutr Soc 74:478-486.

31. Wyness $L$ (2015) The role of red meat in the diet: Nutrition and health benefits. Proc Nutr Soc 25:1-6.

32. Tilman D, Clark M (2014) Global diets link environmental sustainability and human health. Nature 515:518-522.

33. Food and Agricultural Organization (2001) Human energy requirements: Report of a joint FAO/WHO/UNU expert consultation (Food and Agriculture Organization, Rome), Food and Nutrition Technical Report Series, p 96.

34. Seves SM, Verkaik-Kloosterman J, Biesbroek S, Temme EH (2017) Are more environmentally sustainable diets with less meat and dairy nutritionally adequate? Public Health Nutr 20:2050-2062.

35. Bälter K, et al. (2017) Is a diet low in greenhouse gas emissions a nutritious diet?Analyses of self-selected diets in the LifeGene study. Arch Public Health 75:17.

36. Raatz SK, Silverstein JT, Jahns L, Picklo MJ (2013) Issues of fish consumption for cardiovascular disease risk reduction. Nutrients 5:1081-1097.

37. Pauly D, Christensen VV, Dalsgaard J, Froese R, Torres F, Jr (1998) Fishing down marine food webs. Science 279:860-863.

38. Teo K, et al.; PURE Investigators (2013) Prevalence of a healthy lifestyle among in dividuals with cardiovascular disease in high-, middle- and low-income countries: The Prospective Urban Rural Epidemiology (PURE) study. JAMA 309:1613-1621.

39. Bodnar LM, et al. (2017) Racial or ethnic and socioeconomic inequalities in adherence to national dietary guidance in a large cohort of US pregnant women. $J$ Acad Nutr Diet 117:867-877.e3.

40. Sturkenboom SM, et al. (2016) Acculturation and dietary patterns among residents of Surinamese origin in The Netherlands: The HELIUS dietary pattern study. Public Health Nutr 19:682-692.

41. Doyle I-M, Borrmann B, Grosser A, Razum O, Spallek J (2017) Determinants of dietary patterns and diet quality during pregnancy: A systematic review with narrative synthesis. Public Health Nutr 20:1009-1028.

42. Food and Agriculture Organization (2015) Food wastage footprint \& climate change global food loss and waste (Food and Agriculture Organization, Rome), pp 1-4.

43. Finley JW, et al. (2017) Nutritional sustainability: Aligning priorities in nutrition and public health with agricultural production. Adv Nutr 8:780-788.

44. Michalský M, Hooda PS (2015) Greenhouse gas emissions of imported and locally produced fruit and vegetable commodities: A quantitative assessment. Environ Sci Policy 48:32-43.

45. Ulaszewska MM, Luzzani G, Pignatelli S, Capri E (2017) Assessment of diet-related GHG emissions using the environmental hourglass approach for the Mediterranean and new Nordic diets. Sci Total Environ 574:829-836.

46. Wellesley L, Happer C, Froggatt A (2015) Changing climate, changing diets: Pathways to lower meat consumption (Chatham House, The Royal Institute of International Affairs, London).

47. Food and Agriculture Organization (2016) Food Balance Sheets (Food Agric Organ, Rome).

48. Food and Agriculture Organization (2011) Global Food Losses and Food Waste (Food Agric Organ, Rome). Available at www.fao.org/docrep/014/mb060e/mb060e00.pdf. Accessed November 10, 2017.

49. Del Gobbo LC, et al. (2015) Assessing global dietary habits: A comparison of nationa estimates from the FAO and the Global Dietary Database. Am J Clin Nutr 101: 1038-1046.

50. Archer E, Hand GA, Blair SN (2013) Validity of U.S. nutritional surveillance: Nationa Health and Nutrition Examination survey caloric energy intake data, 1971-2010. PLoS One 8:e76632.

51. Usfar AA, Fahmida U (2011) Do Indonesians follow its dietary guidelines? Evidence related to food consumption, healthy lifestyle, and nutritional status within the period 2000-2010. Asia Pac J Clin Nutr 20:484-494.

52. van der Heijden L (2013) Maten, gewichten en codenummers 2003. Informatorium Voo Voeding En Diëtetiek (Bohn Stafleu Van Loghum, Houten, The Netherlands), pp 732-735.

53. Wood R, et al. (2015) Global sustainability accounting-developing EXIOBASE for multi-regional footprint analysis. Sustainability 7:138-163.

54. Heijungs R, et al. (1992) Environmental Life Cycle Assessment of Products: Guide and backgrounds, Part 1 (Institute of Environmental Sciences, Leiden, The Netherlands) Vol 1.

55. Miller RE, Blair PD (2009) Input-Output Analysis Foundations and Extensions (Cambridge Univ Press, Cambridge, UK), 2nd Ed.

56. National Health and Medical Research Council, Department of Health (2013) Eat for health: Australian dietary guidelines (Australian Government, Canberra, ACT, Australia).

57. Ministerium Faruen Gesundheit (2010) Die Österreichische Ernahrunspyramide. Available at https://www.bmgf.gv.at/home/Ernaehrungspyramide. Accessed November 10 2017. German.

58. Minister van Sociale Zaken en Volksgezondheid (2005) Lekker aanbevolen voor jong en minder jong. Available at www.fao.org/3/a-as664o.pdf. Accessed November 10 2017. Dutch.

59. Ministry of Health Brazil (2014) Dietary guidelines for the Brazilian. Available at www foodpolitics.com/wp-content/uploads/Brazilian-Dietary-Guidelines-2014.pdf. Accessed November 10, 2017

60. Health Canada (2011) Food guide servings. Available at www.hc-sc.gc.ca/fn an/alt_formats/hpfb-dgpsa/pdf/food-guide-aliment/view_eatwell_vue_bienmang-eng.pdf. Accessed November 10, 2017.
61. Chinese Nutrition Society (2016) The Chinese dietary guidelines. Available at dg.en. cnsoc.org/. Accessed November 10, 2017.

62. Ministeriet for Fødevarer Landbrug of Fiskeri (2013) De Officielle Kostråd. Available at www.fao.org/3/a-as675o.pdf. Accessed November 10, 2017. Danish.

63. Ministry of Health and the Ministry of Education (2007) National nutrition and exercise guidelines, Ministry of Health. Available at http://www.fao.org/3/a-as673o.pdf. Accessed November 10, 2017.

64. Valtion ravitsemusneuvottelukunta (2014) Suomalaiset Ravitsemussuositukset. Available at www.ravitsemusneuvottelukunta.fi/files/attachments/fi/vrn/ravitsemussuositukset 2014_fi_web.3.pdf. Accessed November 10, 2017. Finnish.

65. Programme National Nutrition Santé (2011) La Santé Vient En Mangeant-Guide Alimentaire Pour Tous. Available at www.inpes.sante.fr/CFESBases/catalogue/pdf/ 581.pdf. Accessed November 10, 2017. French.

66. National Institute for Health Development (2006) Eesti toitumis ja eesti toitumis ja. Available at www.fao.org/3/a-as677o.pdf. Accessed November 10, 2017. Estonian.

67. Supreme Scientific Health Council (1999) Food-based dietary guidelines, Hellenic Ministry of Health. Available at http://www.hhf-greece.gr/hydria-nhns.gr/adultdietary_eng. html. Accessed November 10, 2017.

68. German Nutrition Society (2013) DGE nutritional circle. Available at https://www.dge. de/ernaehrungspraxis/vollwertige-ernaehrung/ernaehrungskreis/. Accessed November 10, 2017

69. An Roinn Sláinte (2012) Your guide to healthy eating using the food pyramid. Available at https://www.healthpromotion.ie/hp-files/docs/HPM00796.pdf. Accessed November 10, 2017

70. Ministry of Health, Labour and Welfare and Ministry of Agriculture, Forestry and Fisheries (2010) Japanese food guide spinning top. Available at www.maff.go.jp/j/ balance guide/b use/pdf/eng reiari.pdf. Accessed November 10, 2017.

71. Veselibas ministrija (2008) Veseliga uztura ieteikumi pieaugusajiem. Available at www.fao.org/3/a-as687o.pdf. Accessed November 10, 2017. Latvian.

72. Istituto Nazionale di Ricerca per gli Alimenti e la Nutrizione (2003) Linee guida per una sana alimentazione Italiana. Available at www.salute.gov.it/imgs/C_17_pubblicazioni_ 652_allegato.pdf. Accessed November 10, 2017. Italian.

73. Brink L, Postma-Smeets A, Stafleu A, Wolvers D (2016) Richtlijnen Schijf van Vijf. Available at www.voedingscentrum.nl/Assets/Uploads/voedingscentrum/Documents/ Consumenten/Schijf van Vijf 2016/VC_Richtlijnen_Schijf_van_Vijf_2016.pdf. Accessed November 10, 2017. Dutch.

74. Health Promotion \& Disease Prevention Directorate (2015) The healthy plate: Dietary guidelines for Maltese adults. Available at health.gov.mt/en/health-promotion/Documents/ library/publications/Healthy plate EN.pdf. Accessed November 10, 2017.

75. Programa Nacional para a Promação de Alimentação Saudável (2003) Dia alimentar, completo equilibrado e variado. Available at nutrimento.pt/noticias/cartaz-porcoesdiarias-recomendadas-segundo-a-nova-roda-dos-alimentos/. Accessed November 10 , 2017. Portuguese.

76. Helsedirektoratet (2014) Anbefalinger om kosthold, ernæring og fysisk aktivitet. Available at https://helsedirektoratet.no/Lists/Publikasjoner/Attachments/806/Anbefalingerom-kosthold-ernering-og-fysisk-aktivitet-IS-2170.pdf. Accessed November 10, 2017. Norwegian.

77. Chabros E, et al. (2010) Zasady Zdrowego Zywienia. Available at www.fao.org/3/ a-as837o.pdf. Accessed November 10, 2017. Polish

78. Park S, Moon S, Kim H, Shim K, Hwang JE (2015) Development of Korean healthy eating index for adults using the Korea national health and nutrition examination survey data. J Nutr Health 48:419-428.

79. Graur M, et al. (2006) Ghid pentru alimentația sănătoasă. Available at www.fao.org/ 3/a-as693o.pdf. Accessed November 10, 2017. Romanian.

80. Rosminzdrav (2015) Healthy eating guidelines. Available at https://goo.gl/ufwy8T. Accessed November 10, 2017.

81. Schweizerische Gesellschaft für Ernährung (2011) Swiss food pyramid recommendations for a healthy and enjoyable adult diet. Available at https://www.ag.ch/media/ kanton_aargau/dgs/dokumente_4/gesundheit_1/gesundheitsfoerderung_praevention/ merkblaetter 1/lebensmittelpyramide/lebensmittel en.pdf. Accessed November 10, 2017.

82. Ribic CH (2007) Priporočila za Zdravo Prehranjevanje. Available at www.fao.org/3/ a-az910o.pdf. Accessed November 10, 2017. Slovenian.

83. Vorster HH, Badham JB, Venter CS (2013) Food-based dietary guidelines for South Africa. South Afr J Clin Nutr 26:32-72.

84. Public Health England (2016) The eatwell guide. Available at https://www.nhs.uk/ Livewell/Goodfood/Documents/The-Eatwell-Guide-2016.pdf. Accessed November 10, 2017.

85. Mari JT, Alias MS, Cruz JN, Ibanez M V. (2010) Una alimentación sana ipara todos! (Ministerio de Sanidad, Política, Social e lgualdad, Madrid).

86. Brugård Konde $\AA$, et al. (2015) Swedish dietary guidelines - risk and benefit management report. Available at http://www.fao.org/3/a-az854e.pdf. Accessed November 10, 2017

87. Food Safety Department Community Nutrition Division (2006) Dietary guidelines for Turkey. Available at www.fao.org/3/a-as697e.pdf. Accessed November 10, 2017.

88. Intergovernmental Panel on Climate Change (IPCC) (2013) Climate change 2013: The physical science basis. Contribution of Working Group I to the fifth assessment report of the Intergovernmental Panel on Climate Change, eds Stocker TF, et al. (Cambridge Univ Press, Cambridge, UK)

89. Huijbregts MAJ, Schöpp W, Verkuijlen E, Heijungs R, Reijnders L (2000) Spatically explicit characteristics of acidifying and eutrophying air pollution in life-cycle assessment. J Ind Ecol 4:75-92. 